\title{
Empirical Research on Special Reserve Balance and Safety Accounting Information Disclosure Level in High-dangerous Industries
}

\author{
En-Zhu Li* \\ School of Accounting \\ Shandong University of Finance \& Economics \\ Ji'nan 250014, China
}

\author{
Xu-Dong Wang \\ School of Accounting \\ Shandong University of Finance \& Economics \\ Ji'nan 250014, China
}

\begin{abstract}
Special reserves are accounting subjects set up by enterprises to extract safety production costs. To a certain extent, the balance of special reserves represents the potential ability to resist safety risks of enterprises. This paper takes 455 listed companies of high-dangerous industries in China Stock Market from 2015 to 2017 as the research samples and the source of the 1,128 observations, and empirically tests the relationship between the company's special reserve balance and the safety accounting information disclosure level. The research results show that there is a significant positive correlation between the company's special reserve balance and the safety accounting information disclosure level. From the perspective of the nature of the industry, a group comparison is made, and it is found that the relationship between the special reserve balance and the safety accounting information disclosure level of companies in the mining and processing industry is more significant. This research combines safety accounting information theory and special reserve theory, expands and enriches the research in two fields, and has certain reference value for government regulators and high-dangerous industry enterprises.
\end{abstract}

Keywords-special reserves; safety accounting; information disclosure; high-dangerous industries

\section{INTRODUCTION}

With economic development and social progress, people are paying more and more attention to safety production. The occurrence of production accidents will cause significant losses to the enterprise, bring huge negative effects to the enterprise, and are not conducive to the development of the highdangerous industry. The National People's Congress, China's Ministry of Finance and China's Safety Supervision Administration also attach great importance to production safety, and successively promulgated a number of laws and regulations such as the "Safety Production Law" and "Administrative Measures on the Extraction and Use of Safety Production Expenses" to promote high-dangerous industries improve its production safety condition and strengthen the disclosure of safety accounting information. Therefore, the improvement of safety accounting information disclosure regulations is conducive to information users' supervision of the company's production safety and improve the highdangerous company's production safety status [1].

This research was financially supported by the Planning Fund of Humanities and Social Sciences of Ministry of Education of P. R. China (Project No.12YJAZH054)
The "Administrative Measures on the Extraction and Use of Safety Production Expenses" also requires enterprises in high-dangerous industries to extract special reserves based on a certain percentage of their annual operating income or output, so the balance of the special reserves can reflect the ability to resist risks of the enterprise to a certain extent for safety production. If the company's special reserve balance is high, it indicates that enterprises in high-dangerous industries have a strong ability to resist safety production risks. In order to establish a good social image and convince information users believe that the company has a good safety status and the ability to reduce safety risks, listed companies in highdangerous industries tend to disclose more safety accounting information. Therefore, there should be a certain correlation between the special reserves of listed companies in highdangerous industries and the level of safety accounting information disclosure. Based on the above considerations, this paper uses samples of listed companies in high-dangerous industries in China Stock Market from 2015 to 2017 to empirically test the relationship between the company's special reserves and the level of safety accounting information disclosure.

The object of this research is mainly reflected in the following two aspects. First, it takes listed companies in highdangerous industries in China as samples, want to finds a correlation between special reserve and the safety accounting information disclosure level, which would broadens the research on special reserve and provides reference for listed companies and regulatory authorities. Second, deeply analyzes the relationship between the special reserve and the security accounting information disclosure level from a new perspective, and further expands the research on the factors affecting the safety accounting information disclosure level.

\section{LITERATURE REVIEW AND HYPOTHESIS}

\section{A. Special Reserve and Safety Accounting Information Disclosure Level}

According to the operating income or output, the highdangerous company draws a special reserve according to a certain proportion. The balance of the special reserve is a potential resource to be used for production safety prevention. 
If the balance of the special reserve in the financial reports of high-dangerous industry listed companies is high, it indicates that the company has a strong ability to resist risks in safety production. For listed companies in high-dangerous industries, the production safety is a major prerequisite, which will have a direct impact on the company's reputation and investment decisions for investors [2]. If the company's special reserve balance is high, it indicates to a certain extent that the company's potential anti-risk ability is relatively strong. In order to establish a good social image and let stakeholders trust that the company has a good safety production situation and potential ability to resist safety risks [3]. Listed companies in high-dangerous industries with high special reserve balances tend to proactively disclose more detailed security accounting information. Based on the above analysis, this paper proposes the first hypotheses:

H1: There is a positive correlation between the balance of special reserves of listed companies in high-dangerous industries and the disclosure level of safety accounting information

\section{B. Special Reserve and Safety Accounting Information Disclosure Levels in Industries of Different Natures}

The high-dangerous industry also includes a number of branch industries. This research deeply divides the highdangerous industries into mineral mining, processing industries and other industries for empirical test. The mining and processing industry is an industry with a higher risk factor among high-dangerous industries, and its production safety risks are also higher. In the event of a safety accident, the economic losses faced by the mining and processing industries are usually greater. In order to respond to the concerns of the society and investors and prove that the company has a good safety production capacity, compared with other industries, the companies in mining and processing industry will pay more attention to safety accounting and disclose higher quality safety accounting information. Based on the above analysis, this paper proposes the second hypotheses:

$\mathrm{H} 2$ : The positive correlation between the balance of special reserves and the level of disclosure of safety accounting information in companies in the mining and processing industry is more significant than in companies in other industries

\section{DATA AND RESEARCH DESIGN}

\section{A. Sample Selection}

T the listed companies in China's high-dangerous industries from 2015 to 2017 are selects as initial samples by this study, and in order to ensure the authenticity of the data, the following screens have been adopted for the data: (1) the listed highdangerous companies that have been specially treated with ST Mark during the observation period are excluded; (2) Listed high-dangerous companies with missing financial data, undisclosed safety accounting information and no special reserve are all exclude; (3) High-dangerous companies that have changed in the industry during the observation period and terminated listing are also excluded. In the end, 455 high- dangerous listed companies that disclosed safety accounting information and extracted special reserves are obtained, and 1,128 observations comes from these 455 high-dangerous listed companies are effective for empirical test. The financial data involved in this study, such as special reserve balances, total assets, asset-liability ratios, total asset returns, and types of executive shareholding ratios, all come from the financial statement database in the CSMAR (China Stock Market Accounting Research) database. By querying the specific items of safety accounting information disclosure in the annual report of each company and using content analysis methods to assign equal weight to the specific disclosure items of each company and quantify the value, then classify and compare the scores of each listed company [5]. Therefore, the overall safety accounting information disclosure score index(SDI) is constructed. In this paper, Winsor tailing processing is performed on all continuous variables by $1 \%$.

\section{B. Variable Definitions}

\section{1) Level of safety accounting information disclosure}

This paper uses the content analysis method to analyze the company's annual report, select the specific items of content related to safety accounting information to score it, so as to evaluate the level of corporate safety accounting information disclosure. Any specific items mentioned in the annual report on safety results, employee safety training, safety expense accrual standards and accounting treatment methods, safety production subsidies and rewards, safety deposits, etc. will receive score of 1 point in same equal weight. There are a total of 11 safety accounting information disclosure items selected by this research to the total score of 11 points, Therefore, the overall Safety Accounting Information Disclosure Score Index (SDI) is formed. This SDI can reflect the level of safety accounting information disclosure in a more detailed and comprehensive manner.

\section{2) Special reserve balance}

The "Administrative Measures on the Extraction and Use of Safety Production Expenses", announced in 2012 by the Ministry of Finance of China and the General Administration of Safety Supervision of China, requires listed companies in high-dangerous industries to accrue safety production expenses and include them in "special reserve" accounting subjects. Therefore, the data of special reserve balance can be obtained from the financial statements published by listed companies in high-dangerous industries. This paper uses the natural logarithm of the value of the special reserve balance in the CSMR database as the explanatory variable of this empirical research.

\section{3) Control variables}

Considering that the company's safety accounting information disclosure levels may be related to financial leverage, the profitability, the size of the enterprise, the growth of the enterprise, the nature of the property rights, etc., in addition to controlling the year and the industry, this study also controls other characteristic variables that may affect the safety investment. When studying the safety investment problem of such Chinese enterprises, the impact of the property rights nature of enterprises should not be ignored. The difference in the nature of corporate property rights has led to differences in 
resource acquisition and responsibility commitments between state-owned and non-state-owned enterprises. Therefore, it is necessary to add attributes of property rights as control variables to the regression model. The specific definition and measurement contents of the variables for the regression model are shown in Table I below.

TABLE I. VARIABLE DEFINITION AND MEASUREMENT

\begin{tabular}{|c|c|}
\hline Variable & Definition \\
\hline$S D I$ & Score based on safety accounting information disclosure \\
\hline SR & $\begin{array}{c}\text { Enterprise special reserve account balance takes natural } \\
\text { logarithm }\end{array}$ \\
\hline REV & $\begin{array}{c}\text { Total liabilities at the end of the period divided by total } \\
\text { assets at the end of the period }\end{array}$ \\
\hline SIZE & $\begin{array}{c}\text { Current net profit divided by total equity at the end of the } \\
\text { logarithm }\end{array}$ \\
\hline$G R O W T H$ & $\begin{array}{c}\text { Increase in total assets at the end of the period divided by } \\
\text { total assets at the beginning of the period } \\
\text { Number of shares held by executives divided by total shares }\end{array}$ \\
\hline STATE & $\begin{array}{c}\text { Virtual variable: When the enterprise is state-owned or } \\
\text { national and local government holding, the value is 1; otherwise, } \\
\text { the value is 0 }\end{array}$ \\
\hline INDUSTRY & $\begin{array}{c}\text { Virtual variable: 2015-2017 a total of 3 years, set 2 dummy } \\
\text { variables } \\
\text { Virtual variable: A total of } 7 \text { industries, set 6 dummy } \\
\text { variables }\end{array}$ \\
\hline
\end{tabular}

\section{MODEL BUILDING}

In order to test the relationship between the special reserve balance of listed companies in high-dangerous industries and the level of safety accounting information disclosure, the following model (1) was constructed and used to test the hypothesis $\mathrm{H} 1$ proposed in the previous section. At the same time, the model was also used to verify the hypothesis $\mathrm{H} 2$ based on industry grouping.

$$
\begin{aligned}
S D I= & \alpha_{0}+\alpha_{1} S R+\alpha_{2} L E V+\alpha_{3} R O E+\alpha_{4} G R O W T H+\alpha_{5} S I Z E+ \\
& \alpha_{6} S T A T E+\alpha_{7} C G+\sum Y E A R+\sum I N D U S T R Y+\varepsilon
\end{aligned}
$$

The variables involved in the above model (1) are specifically defined and measured in Table I, where $\varepsilon$ is the residual term. In this research, the regression analysis is performed by the ordinary least squares method (OLS).

\section{EMPIRICAL ANALYSIS}

\section{A. Descriptive Statistics}

Table II reports descriptive statistics result of the main variables. It can be seen from Table II that the average value of safety accounting information disclosure level (SDI) in the model is 4.330 , the median is 4 , the minimum value is 0 , and the maximum value is 12 , indicating that most listed companies have safety accounting information disclosure, and the distribution of the samples is better. The average value of special reserve level (SR) is 16.06, the median sample is 16.12, the minimum value is 10.07 , and the maximum value is 21.51 , indicating that there is a large gap between the special reserve balances drawn by different companies. The mean, standard deviation, and quantile values of other variables are all within a reasonable range.

TABLE II. DESCRIPTIVE STATISTICS

\begin{tabular}{|l|l|l|l|l|l|l|}
\hline Variable & $\mathrm{N}$ & Mean & Sd & Min & Median & Max \\
\hline SDI & 1128 & 4.330 & 2.540 & 0 & 4 & 12 \\
\hline SR & 1128 & 16.06 & 2.110 & 10.07 & 16.12 & 21.51 \\
\hline LEV & 1128 & 0.460 & 0.200 & 0.0800 & 0.460 & 0.890 \\
\hline GROWTH & 1128 & 0.130 & 0.230 & -0.190 & 0.0700 & 1.300 \\
\hline ROE & 1128 & 0.0500 & 0.0900 & -0.340 & 0.0500 & 0.310 \\
\hline SIZE & 1128 & 22.48 & 1.290 & 20.26 & 22.22 & 26.22 \\
\hline CG & 1128 & 0.0400 & 0.110 & 0 & 0 & 0.560 \\
\hline STATE & 1128 & 0.540 & 0.500 & 0 & 1 & 1 \\
\hline
\end{tabular}

\section{B. Correlation Analysis}

In order to verify the correlation between variables, this paper performs a Pearson correlation test on all the variables that are regressed in the model. As shown in Table III, the correlation coefficient is reported in this table. It can be seen from Table III that the correlation coefficients between the variables are generally small, which indicates that the regression model used in this study does not have the disadvantage of multi-collinearity. So the selected variables and the construction of the regression model are reasonable.

TABLE III. PEARSON CORRELATION COEFFICIENTS BETWEEN VARIABLES

\begin{tabular}{|l|l|l|l|l|l|l|l|l|}
\hline & SDI & SR & LEV & GROWTH & ROE & SIZE & CG & STATE \\
\hline SDI & 1.000 & & & & & & & \\
\hline SR & $0.261^{* * *}$ & 1.000 & & & & & & \\
\hline LEV & $0.070^{* *}$ & $0.246^{* * *}$ & 1.000 & & & & & \\
\hline GROWTH & $-0.085^{* * *}$ & $-0.049 *$ & $-0.081^{* * *}$ & 1.000 & & & & \\
\hline ROE & $-0.078^{* * *}$ & 0.0380 & $-0.168^{* * *}$ & $0.262 * * *$ & 1.000 & & & \\
\hline SIZE & $0.164 * * *$ & $0.517 * * *$ & $0.493^{* * *}$ & $-0.069 * *$ & $-0.054^{*}$ & 1.000 & & \\
\hline CG & $-0.133^{* * *}$ & $-0.112 * * *$ & $-0.186^{* * *}$ & $0.154^{* * *}$ & $0.134 * * *$ & $-0.245^{* * *}$ & 1.000 & \\
\hline STATE & $0.126^{* * *}$ & $0.227 * * *$ & $0.299^{* * *}$ & $-0.220^{* * *}$ & $-0.148^{* * *}$ & $0.421^{* * *}$ & $-0.393 * * *$ & 1.000 \\
\hline
\end{tabular}


It can be seen from the correlation coefficient matrix that the correlation coefficient between the special reserve level (SR) and the safety accounting information disclosure level (SDI) is 0.261 , and it is significantly positively correlated at the level of $1 \%$.

\section{Results of Regression and Its Analysis}

Table IV is based on the empirical results of the previous hypotheses, and the Column 2 in Table IV is the symbol prediction for each variable. It can be seen that the regression results are in line with expectations. Column 3 of Table IV reports the regression results of model (1). It can be seen from the table that the coefficient of special reserve (SR) is 0.154 , and it is significant at the level of $1 \%$, which indicates that the higher the special reserve(SR) drawn by the high-dangerous company, the higher the disclosure level (SDI of Full sample) of safety accounting information in high-dangerous company. Thus, hypothesis H1 is verified, it means that the positive correlation between the balance of special reserves(SR) and the level of disclosure of safety accounting information(SDI) is exist.

TABLE IV. EMPIRICAL RESULTS OF MAIN TEST

\begin{tabular}{|l|l|l|l|l|}
\hline Variable & $\begin{array}{l}\text { Symbol } \\
\text { prediction }\end{array}$ & Full sample & $\begin{array}{l}\text { Mining and } \\
\text { processing } \\
\text { industry }\end{array}$ & $\begin{array}{l}\text { Other } \\
\text { industry }\end{array}$ \\
\hline & & SDI & SDI & SDI \\
\hline SR & + & $0.154^{* * *}$ & $0.169^{* * *}$ & $0.105^{*}$ \\
\hline & & $(4.53)$ & $(3.92)$ & $(1.96)$ \\
\hline LEV & - & -0.225 & 0.397 & $-1.182^{* *}$ \\
\hline & & $(-0.61)$ & $(0.82)$ & $(-2.14)$ \\
\hline GROWTH & - & -0.356 & -0.415 & -0.140 \\
\hline & & $(-1.32)$ & $(-1.03)$ & $(-0.43)$ \\
\hline ROE & + & $1.347^{*}$ & 1.181 & $2.042^{*}$ \\
\hline & & $(1.88)$ & $(1.27)$ & $(1.82)$ \\
\hline SIZE & + & 0.0773 & 0.0303 & 0.148 \\
\hline & & $(1.22)$ & $(0.37)$ & $(1.57)$ \\
\hline CG & - & $-1.106^{*}$ & $-3.993^{* * *}$ & 0.562 \\
\hline & & $(-1.88)$ & $(-4.07)$ & $(0.77)$ \\
\hline STATE & - & -0.00326 & $0.310^{*}$ & $0.437^{* *}$ \\
\hline & & $(-0.02)$ & $(-1.69)$ & $(-1.64)$ \\
\hline Cons & + & $2.535^{* *}$ & $3.463^{* *}$ & 0.696 \\
\hline YEAR & & $(2.00)$ & $(2.14)$ & $(0.36)$ \\
\hline N & & control & control & control \\
\hline Adj. R-sq & & 0.427 & 0.471 & 0.302 \\
\hline & & control & control & control \\
\hline & & 1128 & 646 & 482 \\
\hline & & denote statistical significance at the $1 \%, 5 \%$, and $10 \%$ levels, \\
respectively
\end{tabular}

According to the nature of the industry, the entire sample is divided into two sub-samples of the mining and processing industry and other industries for inspection. The results are shown in column 4 and 5 of Table IV. It can be seen that in the sub-samples of the mining and processing industry, the coefficient of the special reserve (SR) is 0.169 , which is significant at the level of $1 \%$; in the sub-samples of other industries, the coefficient of the special reserve (SR) is 0.0105 , which is significant at the $10 \%$ level. The positive correlation between the balance of special reserves and the level of disclosure of safety accounting information among companies in the mining and processing industry is more significant than that in other industry companies. Hypothesis $\mathrm{H} 2$ is verified.

\section{Robustness Checks}

The data group used in the multiple regression analysis includes the inflation rate factor. Therefore, in the robustness test, first, the previous inflation factor in the data group is replaced by the consumer price index (CPI), that is, the inflation rate is measured by the CPI. On the other hand, the special reserve balance data from 2015 to 2017 was adjusted based on 2014. The previous special reserve balance data was replaced by the adjusted special reserve balance data and the model was regressed again. The coefficient of the special reserve balance variable in consumer price index (P.SR) is 0.154 , which is significant at the level of $1 \%$; the results are shown in Table V. The regression results are shown in Table V, which shows that it is consistent with previous regression results. 
TABLE V. EMPIRICAL RESUlTS OF ROBUSTNESS TEST

\begin{tabular}{|l|l|l|}
\hline \multirow{2}{*}{ Variable } & \multirow{2}{*}{ Symbol prediction } & Full sample \\
\cline { 3 - 3 } & & SDI \\
\hline P.SR & + & $0.154^{* * *}$ \\
\hline & & $(4.53)$ \\
\hline LEV & - & -0.225 \\
\hline & & $(-0.61)$ \\
\hline GROWTH & - & -0.356 \\
\hline & & $(-1.32)$ \\
\hline ROE & + & $1.347^{*}$ \\
\hline & & $(1.88)$ \\
\hline SIZE & + & 0.0773 \\
\hline & & $(1.22)$ \\
\hline CG & - & $-1.106^{*}$ \\
\hline & & $(-1.88)$ \\
\hline STATE & - & -0.00326 \\
\hline & & $(-0.02)$ \\
\hline Cons & + & $2.535^{* *}$ \\
\hline & & $(2.00)$ \\
\hline YEAR & & control \\
\hline INDUSTRY & & control \\
\hline N & & 1128 \\
\hline Adj. R-sq & & 0.427 \\
\hline
\end{tabular}

Note: $* * *, * *$, and $*$ denote statistical significance at the $1 \%, 5 \%$, and $10 \%$ levels, respectively

\section{E. Endogenous Checks}

In order to further alleviate the endogenous problem, this paper uses the instrumental variable method. Taking the special reserve balance (SR) variable lagging one period as an instrumental variable, the two-stage least squares method (2SLS) was used to re-model the regression and restate the main text. From the perspective of the validity of the instrumental variables, the estimation coefficients of the first stage instrumental variable are all significant at the level of $1 \%$, and the estimated $\mathrm{F}$ value of the first stage is 4059.31 , which is obviously greater than the critical value of 16.38 set by Stock $\&$ Yogo in 2005[5], indicating that the instrumental variables are effective and there is no problem of weak instrumental variables. The regression results of the main variables in second stage were consistent with the previous ones, the coefficient of the special reserve balance variable lagging one period (L.SR) is 0.193 , which is significant at the level of $1 \%$; the results are shown in Table VI, indicating that the endogenous problem has been alleviated to some extent, so the previous conclusions are still valid.
TABLE VI. EMPIRICAL RESULTS OF ENDOGENOUS TEST

\begin{tabular}{|l|l|l|}
\hline \multirow{2}{*}{ Variable } & \multirow{2}{*}{ Symbol prediction } & Full sample \\
\cline { 3 - 3 } & & SDI \\
\hline L.SR & + & $0.193^{* * *}$ \\
\hline & & $(5.07)$ \\
\hline LEV & - & -0.220 \\
\hline & & $(-0.60)$ \\
\hline GROWTH & - & -0.343 \\
\hline & & $(-1.28)$ \\
\hline ROE & + & $1.287^{*}$ \\
\hline & & $(1.181)$ \\
\hline SIZE & + & 0.0473 \\
\hline & & $(0.74)$ \\
\hline CG & - & $-1.130^{*}$ \\
\hline & & $(-1.93)$ \\
\hline STATE & - & -0.00734 \\
\hline & & $(-0.02)$ \\
\hline Cons & + & $2.531^{* *}$ \\
\hline & & $(2.01)$ \\
\hline YEAR & & control \\
\hline INDUSTRY & & control \\
\hline N & & 1128 \\
\hline Adj. R-sq & & 0.426 \\
\hline
\end{tabular}

Note: $* * *, * *$ and $*$ denote statistical significance at the $1 \%, 5 \%$, and $10 \%$ levels, respectively

\section{RESEARCH CONCLUSIONS}

This paper uses listed companies in high-dangerous industries from 2015 to 2017 as samples, and made an empirical test of the relationship between the balance of special reserves and the level of safety accounting information disclosure. The empirical results show that there is a significant positive correlation between the balance of special reserves of listed companies in high-dangerous industries and the level of safety accounting information disclosure. The higher the balance of special reserves, the higher the level of safety accounting information disclosure. Further group inspections found that the positive correlation between the balance of special reserves and the level of disclosure of safety accounting information in companies in the mining and processing industry was more significant than in companies in other industries.

At present, there is no clear stipulation on the content and form of safety accounting disclosure in China. Instead, it is up to the high-dangerous enterprises to decide whether to disclose accounting information and how to disclose accounting information by themself. This situation has caused the lack of comparability of the accounting information of the same highdangerous enterprise in different periods and different highdangerous enterprises in the same period. Therefore, the 
establishment of a comprehensive system of safety accounting information disclosure is essential to provide a certain level of safety accounting disclosure. At the same time, makers of accounting information have not paid enough attention to and understanding of accounting information such as the company's special reserve balances. The higher the safety consciousness of the accounting information makers, the more beneficial it is to promote enterprises to improve the level of safety accounting information disclosure. Therefore, improving the safety awareness of information makers plays an more important role then improving the level of disclosure of safety accounting information.

\section{ACKNOWLEDGMENT}

This research was financially supported by the Planning Fund of Humanities and Social Sciences of Ministry of Education of P. R. China (Project No.12YJAZH054).

\section{REFERENCES}

[1] Enzhu Li. Research on the Construction and Application of Safety Accounting Theory System (In Chinese) [D]. Xuzhou: China University of Mining and Technology, 2010

[2] Yang Liyong. Research on the influencing factors of corporate safety accounting information disclosure (In Chinese) [D] Shandong University of Finance and Economics, 2015.

[3] Chen Xianglan. Research on Issues and Countermeasures of Safety Accounting Information Disclosure of Listed Companies in Highdangerous Industries (In Chinese) [J]. Learning of Finance and Accounting, 2017 (18): 88-89.

[4] Luan Qi. Review of Research on Security Accounting Information Disclosure in China (In Chinese) [J]. Financial Accounting Study, 2018 (32): 75-77.

[5] Wan Hui. Research on the Relationship between Security Accounting Information Disclosure and Corporate Value (In Chinese) [D]. Shandong University, 2019. 